QL
596
P $8 C 3$

ENT.

1887

basey, thos. S.

On some Mew Morth America.

Selaphidae.

San Prancisco. 188\%

$\angle$ Bull, Gal. Ocad. Sci. II, 188\% 


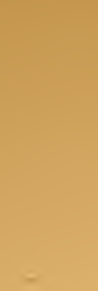

(1) 


ON SOME NEW .

NORTH AMERICAN PSELAPHIDE,

\author{
BY \\ THOS. L. CASEY.
}

Extract from Bulletin 8, California Academy of Sciences.

$$
\begin{aligned}
& 129946 \\
& \text { cung } 29
\end{aligned}
$$





\title{
ON SOME NEW NORTH AMERICAN PSELAPHID互,
}

\author{
(With Plate XVI.) \\ incoln \\ BY THOS. L. "CASEY. \\ Read July 18th, 1887.
}

The Pselaphide fauna of the Pacific coast is by no means so insignificant as it has hitherto been considered, and as the search for these singular and fascinating forms becomes more specialized, and their habits and localities better known, new species are discovered in abundance.

For those who would prosecute a more extended collection of these insects, it may be stated that the Californian Pselaphidæ are very seldom found with ants, although a few myrmecophilous species are known, but generally in fungous earth, about the roots of trees, under bark, or in the long wet moss covering the rocks in the secluded ravines of mountainous regions. The genus Oropus, and several species of Reichenbachia and Batrisus are peculiar to the lastnamed localities, while Euplectus and Pytna are always found under bark. Sonoma and Actium are sometimes found under bark, but often also in fungous earth. Batrisus zephyrinus, on the other hand, I found in abundance at Lake Tahoe, living in the most indiscriminate localitiesunder bark, under chips buried in grassy turf, and in fungous earth.

The following forms, most of which were collected by myself, and which have been accumulating in my cabinet during the past two years, are here described as new, although it is possible that Actium californicum Lec., may be redescribed under that genus. This can only be the case, however, under the supposition that the description given by LeConte for that species is erroneous in regard to the 
length of the elytral strix, and as the species of this genus are numerous and rather local, the probabilities are decidedly against the formation of a synonym.

\author{
Biotus formicarius $n$. gen. \\ Pytna corticina n. gen \\ Batrisus cephalotes. \\ luculentus. \\ foveicornis. \\ punctifrons. \\ Decarthron Brendeli. \\ Bryaxis arizonæ. \\ Nisaxis cincinnata. \\ maritima. \\ Tychus sonomæ
}

Tychns bipuncticeps.

Actium pâllidum.

politum.

robustulum.

testaceum.

Euplectus californicus.

Rhexidius granulosus n. gen.

Oropus montanus.

Sonoma corticina.

cavifrons

\section{BIOTUS n. gen. (Ctenistides.)}

Clypeus simple. Body covered densely with very minute, recumbent setæ. Antennæ elongate. cylindrical, outer joints not enlarged, second joint smallest. Head with two spongiose fover; frontal tubercle divided, the canaliculation extending slightly along the front. Prothorax transverse, with longer, more erect and den*er pubescence, trifoveate at base, the fover large, spongiose, not connected. Elytra with deeply impressed sutural and one long discal stria. Abdomen without ridges; second visible dorsal longer than the first. Posterior coxæ separated. Trochanters normal.

The maxillary palpi are very short, robust and compact; the second joint is somewhat slender, but short; the last two are transverse, anchylosed, forming a circular club which is affixed obliquely to the second joint. No basal joint is visible, and the palpi may possibly be three-jointed. The genus should be placed near Ceophyllus Lec. from which it differs in the remarkably minute and singular palpi. It may be easily identified by its non-clavate antennæ with the"second joint small.

B. formicarius n. sp. - Rather robust, pale testaceo-ferruginous throughout; integuments shining; pubesceuce dense, rather long and erect on the head and prothorax, very short and recumbent on the elytra and abdomen; not perceptibly punctate. Head not much depressed, slightly longer than wide; clypeus rounded, conical; labrum very short, strongly transverse; 
eyes large, coarsely granulate, convex, prominent, at less than their own length from the base; the latter broadly arcuate; occiput having, on a line through the middle of the eyes, two large, feebly impressed, spongiose foveæ, mutually scarcely more distaut than either from the eye; autennæ nearly one-half as long as the body, joints two to ten transverse, cylindrical, first joint flattened, about as long as wide, second small, eleventh slightly longer than the two preceding together. Prothorax distinctly wider than the bead, widest in the middle; sides rather broadly rounded, almost straight near the apex and base; the latter transverse, abruptly arcuate in the middle third, one-third wider than the apex and but slightly narrower than the disk; apex broadly, very feebly emarginate; posterior angles slightly rounded; disk onehalf wider than long, moderately convex, feebly tuberculate in the middle anteriorly; median fovea feebly impressed, elongate, elliptical, beginning at the middle and continuing nearly to the basal margin; lateral fover smaller, circular, deeply impressed, at one-third the length from the base. Elytra at base as wide as the base of the prothorax, at apex three-fourths wider; humeri but slightly prominent; sides evenly arcuate; together very slightly wider than long, each with two large basal foveæ; sutural stria coarse, deep, nearly straight, approaching the suture toward apex; discal coarse, deep, slightly arcuate, continuing for about three-fourths the length. Abdomen slightly narrower than the elytra, about equal in length to the latter; sides nearly parallel, feebly arcuate; border strong, diminishing in width; surface broadly convex. Legs rather long and slender, alutaceous, very densely clothed with minute recumbent setæ; middle trochanters very slender; tarsi rather short; claws small, equal. Metasternum impressed in the middle, more strongly so posteriorly. Length $2.8 \mathrm{~mm}$.

\section{California (Los Angeles 2.)}

The four outer joints of the antennæ are more finely and densely pubescent and slightly paler in color, the eighth joint two-thirds wider than long, much shorter than the ninth or"tenth, the latter nearly equal.

This interesting species lives in the nests of a small pale brown ant.

PYTNA n. gen. ('Tyrides.)

The present genus has the pubescence fine and subrecumbent and not short, robust and recumbent as in the Ctenistides; following the classification suggested by Reitter, it should therefore be placed in the group indicated.

Antennæ approximate; club gradual, three-jointed. Maxillary palpi fourjointed; basal jnint minute; second long, clavate, bent; third shorter, ob- 
conoidal, as robust as the secund; third one-half longer than the serond, fusiform, equal in thickness to the second, acuminate at apex, having a slender terminal process. Head with three small spongiose forer at the apices of an equilateral triangle; eyes large, convex, rather coarsely granu . late; clypeus angulate at the sides. Pronotum with three small basal fover connected by a fine impressed line, Elytra each with oue sutural ana one discal stria. Abdominal border wide, nearly flat; first visible segment with a median basal carina; first two segments equal in length. Prosternum excavated in front of the coxæ; legs rather long; femora slightly robust, the anterior with a short longitudinal carina beneath and near the base; middle tibiæ strongly arcuate; tarsi long and slender, three-jointed; basal joint very small; second and third elongate, the latter the longer; claws simple, moderate in length, equal, slender; anterior trochanters with a small posterior tuberculate tooth; intermediate with a long corneous process, projecting posteriorly from the apex obliquely outward; middle coxæ narrowly, posterior rather widely separated.

The modifications of the trochanters and the inferior carina of the anterior femora are not sexual characters, but are nearly as well developed in the female as in the male. Pytna appears to belong in the neighborhood of Tyrus, but differs in the structure of the palpi.

P. corticina, n. sp.-Bright rufous, abdomen piceous; integuments polished; pubescence fine, rather short, moderately dense. Head very slightly longer than wide, nearly flat above; eyes large, at more than their own length from the base; genæ convergent, feebly arcuate to the neck, clothed with longer, more conspicuous pubescence; foveæ small, the two posterior slightly behind the middle; antennal tubercle slightly transverse, feebly canaliculate in the middle; antennæ long and slender, distinctly more than one-half as long as the body, basal joint subcylindrical, much longer than wide, second slightly narrower, as long as wide, very feebly obconical, three to six subequal, very slightly shorter and narrower than the second, nearly as long as wide, seventh and eighth very slightly smaller, equal, ninth as long as the two preceding together, feebly obconical, one-half longer than wide, tenth as long as the niuth, slightly thicker, feebly obconical, eleventh ovoidal, acuminate, one-half wider than and nearly iwice as loug as the tenth. Prothorax widest at one-third the length from the apex; sides distinctly convergent and nearly straight to the apex; very feebly convergent und just visibly sinuate to the base; the latter broadly and ratber strongly arcuate, scarcely perceptibly narrower than the disk, one-half wider than the apex; the latter transversely truncate; surface convex, impunctate, except near the base; transverse line fine, parallel to the basal margin and distant from it by one-fifth the length; fover very small: disk slightly longer than wide, very 
slightly wider than the head. Elytra one-third longer than the prothorax, at apex more than twice as wide as the latter; sides stiongly divergent, strongly arcuate; humeri rounded, slightly tumid; disk much wider than long, feebly couvex, coarsely but not very densely punctate, truncate behind, the edge densely fimbriate; sutural striæ deep, straight, beginning distinctly before the basal margin; discal arcuate, fine, terminating at nearly one-third the length from the apex, broadly dilated and deeply impressed toward base. Abdomen fully as wide but scarcely as long as the elytra; sides parallel, strongly arcuate; border wide; surface impunctate, strongly convex; basal carina strong. Length 2.0-2.2 $\mathrm{mm}$.

\section{California (Lake Tahoe 11).}

The description is drawn from the male, the sexual modification consisting of a very feeble impression in the middle of the abdomen near the base, and a small deep emargination at the apex of the terminal segment. The female differs but slightly, the terminal segment of the abdomen being broadly angulate at apex.

This species was taken rather abundantly under the bark of various fallen conifers.

\section{BATRISUS Aubé.}

B. cephalotes n. sp.-Somewhat robust, very c snvex, piceous; legs and antennæ pale rufo-ferruginous throughout; pubescence long, coarse, erect, sparse, much denser on the head behind and beneath the eyes, short on the vertex; integuments polished.

Male-Head very large, distinctly wider than long and wider than the prothorax; surface feebly convex; apex very broadly and evenly arcuate throughout the width between the very widely distant antennæ; sides parallel; eyes very small, on the sides just behind the middle, convex, prominent; foveæ round, moderate in size, spongiose, at one-third the length from the base, mutually twice as distant as either from the eye; connecting channel feebly impressed, becoming obsolete anteriorly near the edge of the frontal declivity; vertex abruptly declivous between the antennæ, having in the middle of the lower edge two very approximate teetb, each of which has a deep setigerous puncture on the upper surface near the outer edge; laterally the lower edge is setigerons; vertex beneath the dentiferous edge very deeply excavated throughout the width between the bases of the antennæ; clypeus angulate at the sides, with the edges reflexed, more strongly so at apex which is transversely sinuate; portion before the reflexed apex in the form of a large setigerous tubercle which is further advanced than the two teeth of the upper surface; labrum broadly sinuate, anterior angles promi- 
nent; antennæ robust, as long as the head and prothorax together, club very large, basal joint large, one-half longer than wide, as long as the next two together, lower surface simple but more strongly convex than the upper, second slightly longer and more robust than the third, joints three to eight equal in width, ninth wider, transverse, tenth much wider than the ninth, very slightly wider than long, subglobular, eleventh wider than the tenth, conoidal, apices of joints six to nine slightly oblique; upper surface very coarsely, feebly and sparsely punctate at the sides near the antennæe, elsewhere impunctate, not carinate. Prothorax as long as wide, widest just before the middle, where the sides are strongly rounded and rather prominent, being abruptly and strongly sinuate and rather strongly convergent to the base, broadly rounded to the apex; base scarcely one-fifth wider than the apex, three-fourths as wide as the disk; the latter trisuleate; middle sulcus narrow, deep, obsolete at one-fifth the length from the apex; having near the base a very deep, round, nude median fovea, and two large, spongiose, lateral foveæ, between them bispinose with a longitudinal ridge proceeding anteriorly from each spine, also tuberculate on each lateral edge near the base; surface near the basal margin biforeate laterally, ob soletely and very finely carinate in the middle. Elytra very sparsely, rather coarsely and feebly punctate, each trifoveate at base; discal strix short, broadly, feebly impressed; humeri minutely and distinetly spinose. Abdomen with two short cusps at base. Legs rather long; femora robust; posterior tibiæ with terminal process. Length $2.0 \mathrm{~m} \mathrm{~m}$.

\section{New York 1 (Mr. Henry Ulke.)}

Belongs near denticollis, from which it is easily distinguished by the form of the bidentate vertex, this being declivous, with the teeth upon the lower edge in the present species, and broadly emarginate, with the teeth porrected and but very little below the level of the front in denticollis.*

B. luculentus n. sp.-Rather slender, polished, piceous; elytra slightly paler aud more rufous; legs pale; antenne dark rufous, club paler; pubescence rather sparse.

Male-Head rather large, wider than long, wider than the prothorax, very feebly convex, coarsely, sparsely and feebly punctate anteriorly, impunctate posteriorly; eyes moderate, convex, prominent, near the base; foveæ deep, round, nude, at two-fifths the length from the base, mutually distinctly more than twice as distant as either from the eye; arcuate groove fine, deeply

* Noт\&-From material recently sent me for identification by Dr. Emil Brendel, I find that this species is widely diffused through the North Atlantic districts, there being specimens in the series indicated from New York and Illinois. 
impressed near the foveit, becoming completely obsolete anteriorly; vertex gradually declivous between the antennæ the declivity broadly biimpressed, the impressions setigerous; lower edge bidentate in the middle, the teeth slightly reflexed and with many erect setro on the lower surface, deeply excavated beneath between the antennæ; clypeus broadly arcuate anteriorly, sides feebly divergent posteriorly and nearly straight, angles slightly rounded, not prominent, surface conical, edge not at all reflexed, having in the middle an abrupt, small, strongly elevated tubercle at a considerable distance from the anterior margin and rising just before the two superior teeth, exceedingly minutely and sparsely setose; labrum broadly emarginate, angles prominent; antennæ slightly longer than the head and prothorax together, moderately robust, very strongly clavate, basal joint more convex beneath, not otherwise modified, as long as the next two together, second longer and more robust th: $n$ the third, eighth shortest, strongly transverse, ninth slightly longer and nearly one-half wider than the eighth, transverse, tenth large, nearly twice as wide as the ninth and very nearly as long as wide, sides parallel, arcuate; eleventh distinctly narrower than the tenth, acumisate. Prothorax slightly longer than wide; dorsal ridges and median sulcus almost completely obsolete; median basal puncture small, round, nude, impressed; lateral slightly larger, spongiose; lateral sulcations broadly impressed, feeble; lateral basal tubercles minute; surface near the basal margin bifoveate at the sides, not at all carinate in the middle; disk convex, widest before the middle; sides rather broadly rounded, feebly sinuate toward base and apex; base slightly more than three-fourths as wide as the disk, one-fourth wider than the apex. Elytra fully as long as wide, convex; humeri slightly prominent but not at all spinose. Abdomen with two long, parallel, prominent cusps at base, distant by one-fifth the abdominal width. Legs rather long; femora moderately robust; middle tibiæ with an internal apical spur; posterior feebly arcuate, with a terminal process. Length $1.7 \mathrm{~mm}$.

\section{District of Columbia 2 (Mr. Henry Ulke).}

The female has the vertex strongly declivous, and thence less strongly and continuously so over the surface of the clypeus, which is finely, strongly and densely granulose; the vertex is not excavated between the bases of the antennm, each of which is inserted in a large lateral excavation. The antennæ are more slender, with the outer joints gradually wider, the tenth transverse and but slightly larger than the ninth.

This species should also be placed near denticollis; these three species belong to the nigricans group; the latter is, however, distinguished by the unusual structure of the 
antennæ, the third joint of which is, according to the description of Dr. Le Conte, presumably more robust than the second.

B. foveicornis n. sp.-Rather slender, convex, rufous throughout; integuments polished, impunctate; pubescence rather long, coarse and sparse.

Male-Head moderate, slightly louger than wide, very slightly wider than the prothorax; vertex between the anteunæ coarsely, feebly and not densely punctate, punctures asperate, elsewhere impunctate; eyes small, very convex, prominent, rather finely grauulate; base behind them broadly arcuate; surface very feebly convex, very feebly and tinely carinate in the middle near the base, finely and distiuctly carinate at each side above the eyes; arcuate groove broadly impressed, extending from the base at the sides to the vertex, where it becomes very feeble; fover small, nude, very deep, perforate, situated at less than one-third the length of the superior portions from the base, and on the inuer margin of the arcuate impression; vertex declivous and slightly produced in the middle, being, separated from the clypens by a narrow, feebly impressed transverse groove; clypeus large, prominent, conical, strongly rounded anteriorly, very obtusely angulated at the sides, edges not at all reflexed; antennæ rather slender, as long as the head and prothorax together, basal joint subcylindrical, not modified, nearly as long as the next two together, two to seven subeqnal, distinctly longer than wide, the second slightly more robust and the sixth a very little shorter, eighth equal in width, distinctly wider than long, ninth equal in length to the eighth, one-third wider, inner side much more strongly convergent toward apex, tenth abruptly very large, nearly twice as wide as the ninth, fully as long as wide. flatened, sides parallel, almost straight, eleventh as wide as the tenth, as long as the three preceding together, ob'iquely acuminate, very slightly flattened on the lower side. Prothorax widest slightly before the middle; sides strongly rounded, couvergent and feebly sinuate toward base and apex; median and lateral fover almost equal, deep, at nearly equal distances from the base, the mediau nude; median groove short, feebly impressed, lateral more distinct; basal spines small; ridges distinct, becoming obsolete before the middle, separated behind from the spines by transversely arcuate impressions; base bifoveate at each side; disk strongly convex, very slightly longer than wide, base much wider than the apex. Elytra fully as long as wide, nearly twice as wide as the prothorax, very convex; humeri prominent, not spiuose. Abdomen nearly as wide and as long as the elytra; basal cusps rather long, strong, separated by scarcely one-sixth the abdominal width. Legs long, slender; anterior trochanters minutely toothed posteriorly; posterior tibiæ with an apical process; tarsi very loug and slender, the posterior one-half as long as the tibiæ. Length $1.9 \mathrm{~mm}$.

Tennessee 2 (Mr. Henry Ulke). 
The large flattened tenth antennal joint has, on the lower surface and near the base, a very larye deep circular perforate forea. Of the species in which the tenth antennal joint is enlarged in the males, there are some-for example cephalotes-in which this joint, although unusually large and prominent, is almost completely unmodified upon the lower surface, others - virginice, denticollis, etc. - which have the lower surface slightly flattened and with a small, deep fovea near the base; but in no case which has come under my observation is this fovea one-half so large, or the joint itself so strongly flattened as in the present species.

The two specimens indicated are males. The species probably belongs near spretus Lec., which is described as black.

B. punctifrons n. sp.-Moderately robust, convex, piceous-black; elytra very slightly paler, rufo-piceous; legs and antennæ pale rufo-ferruginous, the latter slightly darker toward base; integuments polished, impunctate; pubescence rather long, sparse, flavate.

Male-Head moderate, slightly longer than wide, just visibly wider than the prothorax; eyes moderate, convex, at their own length from the base; genæ strongly convergent, feebly arcuate; base broadly sinuate; surface feebly convex, very finely, feebly, arcuately carinate above the eyes; impressed groove continuous from the base at the sides to the vertex, at which point it is but slightly more feeble; foveæ deep, nude, in the middle of the groove; vertex coarsely, sparsely and feebly punctate on the antennal tuberculations, which are large and flat, declivous anteriorly, the declivity moderate, beginning aloug a straight line between the antennæ; apex strougly rounded; declivons surface very strongly, finely and densely punctate, each puncture bearing a very miuute, coarse, flavate seta; apex divided from the clypeus by a fine, transverse, strongly arcuate, deeply impressed groove; clypeus short, broadly subangulate, obtusely angulate at the sides; surface finely scabrous, conical; edges not at all reflexed; having in the middle a small, f $\sim$ eble tubercle which bears a tuft of rather long, erect, flavate setæ; antennæ rather long, slender, one-fourth louger than the head and prothorax together, club strong, basal joint not modified, cylindrical, shorter th:n the next two together, second much longer aud distinctly more robust than the third, joints two to seven longer than wide, eightl equal in width, nearly as long as wide, ninth wider and longer, tenth similar to the ninth, distinctly wider and longer, slightly wider than long, inner side much shorter than the outer, eleventh large, twice as wide as the tenth, ovoidal, acuminate, nearly as long as the four preceding toge'her. Prothorax slightly longer 
than wide, widest slightly before the middle; base two-thirds as wide as the disk, one-fourth wider than the apex; median sulcation feebly impressed, becoming obsolete at one-third the length from the apex; spines moderate; ridges almost obsolete; lateral. grooves broadly, feebly impressed; fover large and deep. Elytra fully as long as wide; humeri prominent, not spinose. Abdomen nearly as wide as, but much shorter than the elytra; basal cusps fine, strong, rather long, parallel, separated by one-fifth the abdominal width. Legs long, slender; posterior tibiø with apical process. Length $1.8 \mathrm{~mm}$.

\section{Pennsylvania 1 (Mr. Henry Ulke.)}

This species is very distinct in the characters of the vertex and antennæ; the eleventh joint is here more than usually developed, while the tenth is but slightily larger than the ninth and of nearly the same form.

\section{DECARTHRON Brend.}

D. Brendeli n. sp. - Form somewhat robust, convex, piceo-castaneous throughout; legs and antennæ paler, rufous; pubescence rather long and sparse, more dense on the abdomen and at the sides of the prothorax and head; integuments polished. Head moderate, as wide as long, very feebly convex, almost impunctate; eyes large, coarsely granulated, convex and prominent; genæ extremely short behind them; base wide, transversely truncate; on a line through the anterior portions of the eyes there are two widely distant nude foveæ; antennal tuberculations large, distinctly elevated; antennæ as long as the head and prothor ix together, rather slender, club rather large, basal joint cylindrical, slightly longer than wide, second slightly shorter and narrower, third feebly obconical, as long as and much narrower than the second, four to six subequal, very slightly longer than wide, and just visibly wider than the third, seven larger, scarcely as long as wide, eight very short, transverse, narrower than the seventh, ninth much wider than the seventh, very feebly trapezoidal, nearly twice as wide as long, tenth very slightly wider than the ninth, ovoidal, pointed, nearly as long as the three preceding together. Prothorax scarcely as wide as the head, very slightly wider than long; sides broadly rounded, convergent and feebly sinuate toward base; the latter broadly arcuate, four-fifths as wide as the disk, one-half wider than the apex; disk strongly, evenly convex, not impressed at the sides, having a deep nude fovea in the middle near the base. Elytra near the apex fully twice as wide as the prothorax; sides strongly divergent, arcuate; disk wider than long, two-thirds longer than the prothorax, convex, coarsely and extremely feebly punctate; sutural strix deep, feebly arcute; disc il deeply impressed, feebly arcuate, parallel to the suture, terminating at nearly two.fifths the length from the apex. Abdomen 
two-thirds as long as the elytra, nearly as wide as the latter; first segment when viewed vertically, occupying three-fourths of the entire length, feebly convex; border narrow, flat; basal carinæ strong, very feebly divergent, slightly more than one-half as long as the segment, separated by one-half the entire width. Legs rather long and slender. Length 1.3-1.5 mm.

\section{Texas (Galveston 8).}

The above described type is a male. In this sex the middle femora are very singularly modified, being very strongly swollen, abruptly constricted near the apex, impressed anteriorly, with an anterior tooth near the apex and just before the deep apical constriction. In the female the femora are all simple and rather slender, and the seventh antennal joint is smaller than the eighth. The female is, in addition, smaller than the male, and has the dorsal carine of the abdomen distinctly shorter.

I have dedicated this very distinct species to a friend, the author of the genus, and one to whom our systematic knowledge of the American representatives of the family is greatly indebted.

\section{BRYAXIS Leach.}

B. arizonæ n. sp.-Form rather slender, pale testaceous throughout; shining, not distinctly punctate; pubescence very fine, short and rather sparse. Head moderate, triangular; eyes large, prominent; occipital fover on a line just before the middle of the eyes, mutually more than twice as distant as either from the eye; apical fovea equal to the occipital, slightly less distant from either of the others than the mutual distance of the latter; connecting channel almost obsolete; antenne slender, slightly longer than the head and prothorax together, joints three and five each nearly twice as long as wide, distinctly longer than the fourth and equal in length to the second, the latter more robust, seventh distinctly shorter than the sixth, slightly longer than wide, eighth, ninth and tenth distinctly wider than long, increasing uniformly and very rapidly in size, eleventh wider than the tenth, much longer than wide, obliquely acuminate. Prothorax widest at the middle; sides rounded anteriorly, rather deeply sinuate posteriorly; base broadly, very feebly arcuate, five-sixths as wide as the disk, nearly one-half wider than the apex; the latter very feebly arcuate; disk distinctly wider than long, equal in width to the head, convex; middle fovea slightly smaller than the lateral, the former at one-fifth, the latter at nearly one-third the length from the base. Elytra at the humeri very slightly wider than the prothorax, at 
the apex slightly less than twice as wide as the latter; disk distinetly wider than long, moderately convex; sutural striø strong, nearly straight, convergent and arcuate near the apex; discal fine, feebly impressed, feebly sigmoid, becoming obsolete at one-fifth the length from the apex. Abdomen slightly shorter and very little narrower than the elytra; sides nearly straight and parallel; border moderate in width; surface broadly and feebly convex; first segment, the only one seen when viewed vertically, nearly five-sixths as long as the elytra. Legs slender. Length $1.2 \mathrm{~mm}$.

\section{Arizona (Tuçson 1).}

Described from the male, the sexual characters being similar in form to those of texana, but having the median tubercle of the second segment smaller, less transverse and much more prominent.

This species belongs to the texana group of the genus, which is distinguished by the great development of the first ventral segment in the male, this being the only part of the abdomen seen when viewed vertically. It differs from texana in its smaller size, slightly more robust form, much shorter elytra, narrower abdominal border, in the size and position of the pronotal foveæ, and in its shorter antennæ with less prominent club; the eighth, ninth and tenth joints in texana are much less transverse. In texana the median fovea of the pronotum is larger, and at about one-fourth the length from the base, the three fovew being more nearly on a transverse line than in arizonoe.

\section{NISAXIS Casey.}

N. cincinnata n. sp.-Slightly robust, clear testaceous throughout; legs and antennæ slightly paler; pubescence moderately dense, rather long. Head very slightly narrower than the prothorax, as long as wide; eyes rather large, prominent, at two-thirds their own length from the base; genæ very feebly convergent toward base, feebly arcuate, not at all prominent; base transversely truncate; front large, quadrate, feebly convex, coarsely, deeply, not densely punctate, impunctate in the middle, feebly biimpressed near the vertex; antennæ about as long as the head and prothorax together, first two joints nearly equal, slightly more robust, one-half longer than wide, nearly cylindrical, third obconical, longer than wide, much shorter than the second, as long as the fifth, longer than the fourth, sixth and seven th slightly shorter, very little longer than wide, eighth very slightly wider, a little wider than 
long, shorter than the seventh, ninth two-thirds wider than the eighth, obtrapezoidal, outer side more oblique, tenth one-half longer and wider than the ninth, one-half wider than long, eleventh distinctly wider than the tenth, as long as the three preceding together, longer than wide, obliquely acumiminate. Prothorax widest at two-fifths the length from the apex; sides strongly rounded, feebly incurvate toward base; the latter broadly, evenly arcuate, three-fourths as wide as the disk, nearly two-thirds wider than the apex; disk one-third wider than long, evenly convex, rather coarsely, extremely feebly aud not densely punctate; having in the middle, at one-fifth the length from the base, a small nude punctiform forea, and, at each side, a larger feebly impressed nude fovea at one-third the length from the base. Elytra at the humeri distinctly wider than the prothorax, together distinctly wider than long, one-half longer than the pronotum, and, at apex four-fifths wider than the latter; disk moderately convex, sutural stria deeply impressed, evenly, feebly arcuate; discal fine, distinct, extending very slightly beyond the middle; sutural foven very small and at the extreme basal margin; lateral larger and further from the base; base otherwise devoid of foveæ; surface very minutely, feebly and sparsely punctate. Abdomen two-thirds as long as the elytra, nearly equal in width, occupied for six-sevenths the entire length when viewed vertically by the basal segment; border rather narrow, flat; surface moderately convex, finely, feebly and sparsely punctate; basal carinæ divergent, straight, strong, nearly one-half as long as the segment, separated by one-half the abdominal width. Legs rather long and slender; posterior tibiæ abruptly bent near the apex, middle coxæ large, globose, not prominent, distinctly but narrowly separated by the sternal processes which are truncate and not carinate; posterior small, widely separated. Length $1.1 \mathrm{~mm}$.

\section{Texas (Galveston 10).}

Described from the male in which the first two dorsals are simple, the third transversely and feebly impresser, the impression large and anteriorly lunate, the inclosed apical elevation being feebly convex and bearing a loose tuft of long erect setæ; fourth and fifth normal, broadly arcuate at apex, the latter short and with the posterior margin very feebly produced in the middle. Viewed from beneath the abdomen consists of three visible segments, although there is probably a fourth which is completely hidden under the third; the basal segment is very long, and, in the middle, occupies the entire extent, except a very small apical portion where the two short posterior segments become very short, the third being at this point deflexed and channeled 
externally. Besides the tuft of long setre from the median elevation of the third segment, there are many long conspicuous setro on the second, and at the sides and base of the third.

N. maritima n. sp.-Form somewhat slender, dark rufous throughout; elytral apices slightly darker; legs and antennæ very slightly paler; pubescence long, rather coarse, not dense. Head slightly narrower than the prothorax, nearly as wide as long; eyes moderate, at nearly their own length from the base; genæ feebly arcuate, not at all prominent, as long as the eye; front feebly convex, feebly, finely and sparsely punctate toward the eyes, impunctate in the middle; antennæ slender, about as long as the head and prothorax together, nearly as in cincinnata, ninth joint symmetrical, but slightly wider than long, tenth strongly transverse, truncate at base and apex, nearly eylindrical, eleventh elongate, but slightly wider than the tenth. Prothorax one-fourth wider than long, widest before the middle; sides strongly rounded, strongly sinuate near the basal angles; base broadly arcuate, nearly four-fifths as wide as the disk, one-half wider than the apex; surface very minutely, feebly and sparsely punctate; basal fovea very small, at one-fifth the length from the base; lateral moderately deep, larger, at onefourth the length from the base. Elytra slightly wider than long, at apex four-fifths wider than the prothorax; sides feebly divergent; disk rather strongly convex; sutural striø strong, feebly arcuate; discal fine, distinct, extending from near the base for two-thirds the length. Abdomen but slightly more than one-half as long as the elytra; border rather narrow; basal carinæ short, one-fifth as long as the bas al segment, divergent, feeble, separated by slightly more than one-half the abdominal width. Legs long and slender; posterior tibiæ bent near the apex. Length $1.0 \mathrm{~mm}$.

\section{Texas (Galveston 3.)}

The description is taken from the male, the sexual characters being very remarkable. The first dorsal segment occupies nearly the entire extent of the abdomen when viewed vertically, and has the apex abruptly deflexed in the middle, the deflexed portion being transversely impressed or excavated; its lower margin is reflexed and broken into two lateral crests and a small median and strongly elevated tubercle; the edge of the segment immediately above the deflexed excarated portion is more densely setose and bears two feeble tubercles. The second segment is short, transversely and very deeply excavated in the middle third, the 
excavation being anteriorly arcuate and extending under the apical process of the first; at the apex there is in the middle a strongly elevated carinate tubercle which is slightly transverse, with the apex directed anteriorly for a slight distance over the excavation, and bearing two fine setiform appendages; its posterior surface is feebly and minutely tuberculate; the surface of the segment has, at each side of the central excavation, a transverse arcuate canaliculation which is disconnected. The third segment has, just before the middle, two small tubercles distant by nearly one-half the width, the remainder of the surface being unmodified. Fourth segment unmodified. Fifth shorter, feebly produced in the middle.

The under surface, as in cincinnata, consists of but three visible segments, the first being very long, the third abruptly and narrowly deflexed in the middle, the deflexed portion being channeled externally. There is, however, a fourth segment to be seen by looking longitudinally under the third, by which it is entirely covered. The surface of this fourth segment is abruptly arched at each side between the middle and the lateral edges, the arching being visible as a semicircular emargination of the edge when viewed longitudinally, and there is on the edge in the middle a strong vertical spine which appears to fit into the channel in the deflexed apex of the third segment.

These species belong near tomentosa Aubé, but appear to be smaller and more sparsely pubescent. The genus is almost exclusively confined to the sea-beaches of the Atlantic coast.

\section{TYCHUS Leach.}

T. sonomæ n. sp.-Slender, convex, piceous; elytra, legs and antennæ testaceous; pubescence fine, moderate in length, sparse; integuments polished, impunctate. Head much narrower than the prothorax, distinctly longer than wide, broadly rounded behind the eyes; the latter rather large, prominent, coarsely granulate, at nearly their own length from the base; surface transversely convex, transrersely impressed behind the frontal 
tubercle, which is transverse, convex and impressed along the middle; on a transverse line passing through the anterior portirin of the eyes there are two minute, widely distant, punctiform fover; antennæ slightly longer than the head and prothorax together, robust, strongly clavate, basal joint much longer than wide, arcuate, second slightly narrower, quadrate, third narrower, obconical, longer than wide, joints three to seven subequal, eighth very slightly wider than long, ninth abruptly much wi ler, tenth still wider, equal in length, ninth and tenth distinctly wider than long, eleventh wider than the tenth, as long as the three preceding together, acuminate. Prothorax widest slightly before the middle, as wide as long, strongly convex; sides rather strongly rounded, feebly sinuate near the apex, more strongly so near the base; the latter broadly arcuate, four-tifths as wide as the disk, one-third wider than the apex; basal fovea minute, very near the margin; lateral impressions feeble; along the basal margin between the median fover and the basal angles there are, on each side, two small punctiform foveæ, nearly as large as the median. Elytra at the humeri scarcely perceptibly wider than the prothorax, at the apex nearly twice as wide as the latter; sides evenly arcuate, together transversely truncate behind, convex, as long as wide, two-thirds longer than the prothorax; each bifoveate at base; sutural stria deeply impressed; discal distinct, broadly impressed, terminating slightly before the middle. Abdomen two-thirds as long as the elytra, much narrower than the latter, parabolic in form; basal segment much longer than the second; lateral border narrow, flat, rapidly attenuate from base to apex. Legs rather long and slender; posterior tibiæ arcuate toward apex. Length $1.25 \mathrm{~mm}$.

\section{California (Mendocino Co., 1.)}

The specimen described is probably a male; the sexual characters are very feeble, the fifth segment being longer, feebly flattened, and broadly bilobed at apex. The species is much smaller than either of the two previously described from these regions, and the fourth joint of the maxillary palpi has a long and distinct terminal process. The third joint of that organ is elongate and clavate, the fourth more strongly arcuate within, subsecuriform, elongate and strongly compressed.

T. bipuncticeps n. sp.-Rather slender, convex, polished, impunctate, piceous; elytra, legs and antennæ pale rufous. Head moderate, slightly longer than wide, convex; eyes large, convex, prominent, just behind the middle; genæ convergent, feebly arcuate, clothed with longer, dense pubescence; base broadly arcuate; antennal tubercle much wider than long. large, divided by a feeble canaliculation; antennæ as long as the head and 
prothorax together, rather slender, basal joint as long as the next two together, subcylindrical, second narrower, second and third slightly longer than wide, the latter slightly shorter and narrower, four to eight equal in width, slightly shorter but scarcely narrower than the third, ninth wider, nearly as long as wide, tenth wider than the ninth, wider than long, eleventh distinctly wider than the tenth, ovoidal, acuminate, as long as the three preceding together; on a line through the anterior portions of the eyes there are two small, very widely distant nude punctures; fourth joint of maxillary palpi dilated internally, truncate at apex, having a slender terminal process. Prothorax distinctly wider than the head, one-fifth wider than long; sides strongly rounded just before the middle, convergent and very feebly sinuate toward base; the latter evenly, feebly arcuate, four-fifths as wide as the disk, one-third wider than the apex; the latter truncate; disk strongly convex, with a row of small punctures along the basal margin, very feebly impressed at each side near the base, with a small, deeply impressed, nude fovea in the middle and very near the basal margin. Elytra near the apex nearly twice as wide as the prothorax; sides moderately divergent from base to apex, arcuate; disk fully as long as wide, convex; sutural striæ distinct, strongly arcuate; discal fine, distiuct, terminating at the middle; humeri rather strongly tumid. Abdomen much shorter than the elytra, parabolically rounded throughout; border narrow, rapidly becoming extinct; surface convex and declivous posteriorly from the apex of the first visible segment; the latter as long as the next two together, transversely very feebly conver. Legs long, slender, simple; tarsi slender. Metasternum broadly and strongly impressed along the midale; posterior coxæ rather widely separated. Length $1.4 \mathrm{~mm}$.

\section{California (Lake Tahoe 2).}

The type specimen is a male, the under surface of the abdomen near the apex being broadly and feebly impressed. With this specimen I have associated a female, which differs considerably in the much shorter elytra, with more strongly divergent sides; but the material is insufficient to permit definite conclusions regarding its identity.

The individual facets or granules upon the surface of the compound eyes are circular and very widely separated.

This species is very nearly related to sonomce, but differs in its slightly more robust form and slightly more transverse prothorax, with more angulate sides. It occurs under chips and bark slightly buried in grassy turf. 


\section{ACTIUM Casey.}

Through the kindness of Herr Reitter, of Mödling, Austria, who has sent me several representatives of Trimiopsis, I am enabled to give the following statement, showing the relationship of the latter with Actium, Trimiopsis being represented by 7 . Eggersi.

The maxillary palpi of Trimiopsis are long, the fourth joint being more strongly dilated internally near the base, and therefore distinctly securiform; while in Actium, as represented by pallidum, the palpi are shorter, more robust, and with the outer joint ovoidal and acuminate. In I. specularis, however, the palpi are more robust and do not differ so greatly from the form existing in Actium.

One of the most conclusive differences, however, is the presence of a distinct discal stria, extending for one-half to two-thirds the elytral length in Actium, and the complete absence of this stria in Trimiopsis.

In Trimiopsis the isolated fovea at the base of each elytra, between the discal and sutural strix, which is a constant character of Actium, is completely wanting.

Several species of Trimiopsis have two basal abdominal carinæ, these being very widely distant in T. specularis; others, however,-eg. Eygersi-are entirely devoid of the basal carinæ. In Actium the basal carinæ are distinct and rather approximate.

The species of Trimiopsis are much smaller than those of Actium, and have the head relatively much larger.

Actium also appears to resemble, to some extent, the much more minute African species, recently described under the name Periplectus by Raffray,

It is probable that the species described from the eastern parts of the United States under the name Trimium might more appropriately be referred to Trimiopsis, as the European genus Trimium has not yet been discovered within our territories. 
A. pallidum n. sp.-Form rather slender, convex; pale flavo-testaceous throughout, antennæ and legs slightly paler and less rufous; integuments polished, impunctate; pubescence fine, short, subrecumbent, rather sparse. Head small, very much narrower than the prothorax; as long as wide; eyes rather large and prominent, somewhat finely granulated, at the middle of the sides; genæ distinctly shorter than the eyes, evenly rounded to the neck, not at all prominent; base very feebly sinuate; occiput longitudinally impressed in the middle; front having two round, impressed, spongiose fover on a line through the middle of the eyes, mutually twice as distant as either from the eye, connected by a subangulate channel which is rather strongly impressed and much wider than long; antennæ short, one-half longer than the head, club very robust, two baśal joints subequal, slightly longer than wide, more robust than the funicle, joints three to seven moniliform, subequal, the former slightly longer than wide, the latter slightly transverse, joints eight to ten very short and strongly transverse, equal in length, acutely rounded at the sides, the former twice, the latter more than three times as wide as long, eleventh much wider, ovoidal, gradually acuminate, as long as the five preceding together. Prothorax widest at one-third the length from the apex, where it is scarcely as wide as long; sides rather broadly rounded, feebly convergent and nearly straight toward base; the latter evenly and rather strongly areuate throughout, fully four-fifths as wide as the disk, one-half wider than the apex; disk convex, having at one-fourth the length from the base a transverse, narrow, deeply impressed, posteriorly arcuate channel, connecting the rather large, deeply impressed, spongiose lateral fover and continued posteriorly more than one-balf the distance to the basal margin by a canaliculate impression; along the basal margin, very near the edge. there is a narrow deeply-impressed line. Elytra at the humeri much wider than the prothorax; sides feebly divergent, arcuate; humeri rather prominent; together fully as long as wide; disk feebly convex, each trifoveate at base; sutural stria fine, deep, nearly straight; diseal proceeding from the third fovea, tine, nearly straight, parallel to the sutural, slightly double at base, vanishing at a slight distance before the middle; second fovea without trace of stria. Abdomen distinctly shorter, but very slightly narrower than the elytra, rapidly declivous behind, parabolically rounded through its apical half when viewed vertically; border narrow, slightly inclined; first segment slightly longer than the second, having at base two fine, slightly divergent carinæ which are very short and distant by less than one.fifth the abdominal width. Legs slender. Length $1.2 \mathrm{~mm}$.

\section{California (Monterey Co.)}

This species is abundant under decomposing vegetation, near the margins of small streams.

A. politum n. sp.-Form slender, convex; bight testaceous, legs and antennæ slightly paler, more flavate, abdomen dirker, castaneous; integu- 
ments polished, impunctate; pubescence fine, short, sparse. Head small, as long as wide, distinctly narrower than the prothorax; eyes rather suall, at the middle of the sides, convex; genæ distinctly longer than the eyes, arcuate, not prominent; occiput feebly impressed in the middle; front having two large spougiose fover on a line through the posterior portions of the eyes and mutually twice as distant as either from the eye, connected by a subangulate impressed groove; antennæ short, slender, scarcely one-half longer than the head, club large, elongate, two basal joints more robust, subequal, slightly longer than wide, joints three to seven moniliform, the latter globular, eighth very slightly wider, a little wider than long, eight to ten very gradually wider and more transverse, equal in length, the latler oval and scarcely twice as wide as long, eleventh nearly twice as wide as the tenth, cylindro-conoidal, acruminate, truncate at base, elongate, nearly as long as the tive preceding together. Prothorax widest at two-fifths the length from the apex; sides rather strongly rounded, distinctly convergent and feebly sinuate to the basal angles; base feebly arcuate, scarcely more than two-thirds as wide as the disk, one-third wider than the apex; disk convex, about as wide as long, crossed at one-third the length from the base by a narrow impressed groove which is nearly straight; lateral fover large, spongiose, deeply impressed; median posterior prolongation rather broadly impressed; basal margin feebly impressed. Elytral width at the humeri, which are distinctly prominent, much greater than that of the prothorax; sides very feebly divergent, evenly and strongly arcuate; together as long as wide, transversely truncate at apex; disk feebly convex, each trifoveate at base; sutural strio deep, feebly and evenly arcuate, rather distant from the suture; discal feebly arcuate, parallel, vanishing very slightly behind the middle, distinctly double at base. Abdomen distinctly shorter and narrower than the elytra; sides parallel and straight at base, rounded behind; border rather narrow; first visible dorsal with two fine subparallel basal carinæ which are nearly one-third as long as the segment and separated by nearly one-fourth the abdominal width. Legs slender. Length $1.3 \mathrm{~mm}$.

\section{California (Mendocino Co. 1).}

Easily known by its dark abdomen, slender antennæ and smaller eyes.

A. robustulum n. sp.-Rather robust, convex, pale testaceous throughout; integuments polished, impunctate; pubescence fine, short, subrecumbent, not dense. Head very small, nearly as wide as long, much narrower than the prothorax; eyes moderate, convex, prominent; genæ distinctly longer than the eye, not prominent, rounded; occipital foven large, on a line through the posterior portions of the eyes, mutually twice as distant as either from the eye, connected by an impressed angulate groove; antennæo short and slender, scarcely one-half longer than the head, club gradual, elongate, two basal joints subequal, slightly more robust, longer than wide, 
three to seven nearly equal in width, the former much longer than wide, the latter distinctly wider than long, ninth to eleventh uniformly and rather rapidly increasing in widtb, the ninth one-half wider than long, slightly shorter than the tenth, the latter fully twice as wide as long, eleventh elongate, accuminate, as long as the four preceding together. Prothorax widest before the middle; sides rounded, convergent and feebly sinuate toward base; the latter evenly and distinctly arcuate, four-fifths as wide as the disk and one-half wider than the apex; disk convex, very slightly wider than long; basal groove at nearly one-third the length from the margin, feebly, posteriorly arcuate, very deeply impressed; lateral foveæ large, deeply impressed, median posterior cusp shaped prolongation large and long; surface broadly and very feebly impressed anteriorly from the lateral fover, and with traces of a narrow median canaliculation near the center of the disk. Elytra at the somewhat prominent humeri distinctly wider than the prothorax; sides very feebly divergent, strongly and evenly arcuate; disk about as long as wide, convex; sutural striæ deep, arcuate; discal fine, distinct, nearly parallel, extending to or very slightly beyond the middle; intermediate basal forea sim. pie. Abdomen viewed vertically short and broad, three-fourths as long as the elytra, distinctly narrower; sides straight, parallel, broadly rounded behind; border rather narrow, inclined; first visible segment very slightly longer than the second; basal carinæ rather robust and flat, very feebly divergent, less than one-third as long as the segment, distant by one-fourth the abdominal width. Legs moderate in length; femora robust, much more arcuate externally and toward apex, posterior more slender. Length 1.4 $\mathrm{mm}$.

California (Anderson Val., Mendocino Co. 1).

The type is apparently a male, the penultimate segment being transversely and narrowly impressed; the terminal segment is flat, in appearance like a horizontal pygidium; it is slightly longer than wide, oval, slightly more attenuate behind, and entirely surrounded by the other segments. The species is much more robust than the others here described.

A. testaceum n. sp.-Form slender, convex; pale testaceous throughout; integuments polished, almost impunctate; pubescence very fine, short, sparse. Head moderate, distinctly narrower than the prothorax; eyes small, convex, prominent; genæ not at all prominent, wuch longer than the eye, rounded; occiput narrowly and deeply impressed in the middle; fover on a line through the posterior portions of the eyes, round, spongiose, scarcely twice as distant as either from the eye, connected by an impressed channel, which is more broadly arcuate than usual; antennæ scarcely onehalf longer than the head, slender, nearly as in robustulum. Prothorax 
very slightly wider than long, almost exactly similar to that of robustulum, except that the transverse basal groove is at scarcely more than one-fourth the length from the base. Elytra at the prominent humeri distinctly wider than the prothorax; sides feebly divergent, strongly arcuate; disk convex, about as long as wide; sutural striæ strong, arcuate; discal fine, distinct, terminating at the middle of the disk. Abdomen very slightly shorter and much narrower than the elytra, longer than wide; sides nearly parallel, straight, except in the apical fourth, which is parabolically rounded; basal carinæ less than one-third as long as the segment, fine, exactly parallel and straight, separated by slightly less than one-third the abdominal width. Legs rather short and slender. Length $1.2 \mathrm{~mm}$.

\section{California (Anderson Val., Mendocino Co. 1).}

'This species is very closely allied to the preceding, the type specimen, which is apparently a female, is smaller, much narrower, with a narrower, much more elongate abdomen and larger head. The form and position of the basal carinæ differ in the two species, being distinctly stronger and divergent in robustulum, and finer and perfectly paralle] in testaceum. Were it not for this character and the probability-because of the sexual characters-of the masculinity of the small-headed type of robustulum, I should be persuaded to unite the two as very extreme specimens of a single species, but at present this does not appear to be admissible. Althongh both are from the same region, the localities in which they were taken were widely different.

The four species thus far described differ from californicum, as described by LeConte, in the extent of the discal striæ, these being two-thirds as long as the elytra in the latter. The number of species is probably considerable, as scarcely any organized attempt has been made to collect them.

\section{EUPLECTUS Leach.}

E. californicus n. sp.-Form slender, parallel, depressed; dark testaceous throughout, polished; pubescence fine, rather short, somewhat dense. Head rather large, slightly wider than long; eyes small, convex, rather prominent, at more than their own length from the base; genæ rounded, convergent, not prominent; base broadly sinuate; surface depressed, coarsely, deeply and rather densely punctate; having on a line through the 
middle of the eyes, two small nude fover, mutually scarcely as distant as either from the eye, connected by a feebly impressed anterior groove; antennal tuberculations small, rather prominent; antennæ three-fourths as long as the head and prothorax together, moderately robust, club moderate, the joints nine to eleven gradually and uniformly wider, the latter oval, as long as the three preceding together; under surface deeply and densely punctate, with an impressed fovea in the middle at the base, without long erect setæ. Prothorax slightly shorter and narrower than the head, widest at one-third the length from the apex, very slightly wider than long; sides strongly rounded anteriorly, rather strongly convergent and nearly straight to the base; the latter broadly arcuate, two-thirds as wide as the disk, very slightly wider than the apex; the latter transversely truncate; disk feebly convex, with a slightly elongate foveæ near the center, a broad impression at one-fourth the length from the base, and, on each side, a large rounded deeply-impressed foveæ, at two-fifths the length from the base, not connected with the median impression; surface very feebly and not densely punctate. Elytra at the humeri slightly wider than the prothorax; sides nearly parallel, distinctly arcuate; together very feebly sinuate at apex; disk depressed, as long as wide, nearly one-half longer than the prothorax; sutural stria deep, very feebly arcuate; discal fine, distinct, slightly arcuate, vanishing slightly before the middle; each elytron with an isolated basal fovea near the sutural; surface very feebly, sparsely punctate. Abdomen as long as the elytra and distinctly narrower; sides straight and parallel; border narrow; surface feebly convex, finely, feebly and not densely punctate; first three visible dorsals equal in length; first two each impressed in the middle of the base; carinæ very short and nearly obsolete. Legs short; femora not robust; tarsi short and robust. Metasternum long, impressed along the middle. Length $1.3 \mathrm{~mm}$.

\section{Califormia (Lake Tahoe 3).}

The tarsal claw has a very minute hair-like appendage internally near the base, giving the appearance of a rudimentary second claw, but as all the characters are precisely similar to the European genus Euplectus, as seen in sanguineus, signatus, Bonvouloiri, etc., much more, similar, in fact, than most of our Eastern Euplecti, it is impossible to believe that it belongs to a different group. I would prefer rather to consider this a tendency to revert to the normal condition of Coleoptera, and to hold that similar appearances may occasionally be exhibited in the European genus.

The type is a male, the sixth segment being deeply in- 
pressed in the middle. The female does not differ appreciably in form.

The occurrence of a genuine Euplectus near the Pacific coast is a very interesting fact, as heretofore the genus has not been discovered west of the Rocky Mountains. The three specimens indicated were found under the bark of fallen trees, and the species appears to be very rare. It should be placed after confluens in our lists.

\section{RHEXIDIUS n. gen. (Euplectini)}

Tarsi with two unequal claws; antennæ straight, basal joint not conspicnously elongate, widely separated at base. Posterior coxæ contiguous. Prothorax without lateral teeth, having a median canaliculation, and two large lateral foveæ near the base connected by a fine transverse line. Antennæ eleven-jointed, short; club long and slender, three-jointed. Maxillary palpi small, sleuder; third joint oval, slightly longer than wide; fourth much longer than the three basal combined, slender, fusiform. First visible dorsal segment slightly longer than the second; second ventral in the middle as long as the next three together; posterior margins of the posterior segments strongly emarginate. Elytra with lateral subhumeral fovea and fine carina.

This genus is founded upon a small Californian species, bearing a great resemblance in many of its characters to Oropus, but differing in the structure of the antennæ and in the complete absence of lateral prothoracic teeth. It belongs in some of its characters near the African genus Raffrayia, Reitter, but differs greatly in the pronotal sculpture and elytral structure.

R. granulosus n. sp.-Rather slender and depressed, pale ochreous-testaceous throughout, slightly shining; pubescence rather coarse, moderate in length, not very dense. Head much wider than long; eyes far down on the sides, rather small, feebly convex, at about their own length from the base, coarsely granulated; base broadly sinuate; occiput feebly impressed in the middle at base, having dorsally on a line through the middle of the oyes two small, very widely distant, nude foveæ, also near the apex a transversely and feebly arcuate groove, terminating in minute foveæ which are connected with the occipital foveæ by a finer groove; surface impunctate, rather densely covered with small, round, strongly elevated tubercles; antennæ distinctly shorter than the head and prothorax together, basal joint but very 
slightly longer than wide, cylindrical, secund shorter, slightly narrower, nearly globular, three to eight narrower, transverse, the latter twice as wide as long, ninth and tenth slightly more than twice as long, much longer than the eighth, nearly rectangular, the tenth very slightly the wider and longer, eleventh scarcely visibly wider than the tenth, very elongate and slender, gradually acuminate and as long as the five preceding joints combined. Prothorax but very slightly wider than the head, widest in the middle; sides near the basal angles just visibly sinuate, in the middle strongly rounded, near the apex very feebly sinuate; base broadly arcuate, two-thirds as wide as the disk, one-half wider than the apex; disk as wide as long, moderately convex, covered not very densely with small tubercles; median canaliculation rather fine, equal, terminating near the base and apex; lateral fove: small, deeply impressed, spongiose, at a little more than one-fourth the length from the base, connecting groove transverse, straight, very fine. Elytra slightly longer than the prothorax, at apex one-half wider than the latter, distinctly wider than long; humeri not at all prominent; together transversely truncate behind; disk feebly convex, rather sparsely and more coarsely tuberculate, each with three basal foveæ and four striæ, one evenly and feebly arcuate, two and three feeble, nearly equal, one-half as long as the elytra, four stronger, one-third as long as the elytra. Abdomen very slightly wider and longer than the elytra; sides arcuate; border rather strong, inclined; surface rather strongly convex, scarcely visibly tuberculate, Legs rather slender. Length $1.0 \mathrm{~mm}$.

\section{California (Alameda 4).}

The sexual differences are apparently very feeble, the terminal segment in the male being feebly impressed. The mesosternum is bicarinate.

\section{OROPUS Casey.}

0. montanus n. sp. - Form slender, rather depressed, uniform dark rufo-testaceous throughout; integuments polished, not perceptibly punctate; pubescence fine, rather long, not dense. Head triangular, shorter and narrower than the prothorax; eyes rather small, not very prominent, at slightly more than their own length from the base; genæ strongly convergent, feebly arcuate; base broadly sinuate; base of occiput longitudinally impressed in the middle; occipital fover deep, distant, on a line through the posterior limits of the eyes, connected by a narrow, deeply impressed, arcuate groove, much shorter than wide; antennæ short, robust, distinctly shorter than the head and prothorax together, club elongate, rather feeble, joints three to eight transverse, the former slightly wider than long, the latter more than twice as wide as long, ninth and tenth joints twice as wide as long, nearly rectangular, tenth just visibly wider and longer than the ninth, eleventh 
distinctly wider than the tenth, nearly three-fourths longer than wide, conoidal, acuminate. Prothorax widest in the middle, where the sides are strongly rounded, thence strongly convergent toward base and apex, very feebly sinuate near each limit; base broadly arcuate, scarcely two-thirds as wide as the disk, one-half wider than the apex; the latter feebly arcuate and less than one-half as wide as the disk; lateral teeth minute, in a transverse line with the lateral foveæ; the latter deep, at slightly less than one-third the length from the base, connected by a fine, posteriorly arcuate groove; median canaliculation fine, crossing the transverse groove; obsolete near the base and apex, not at all dilated except near its basal limit; disk about as long as wide. Elytra scarcely one-fifth longer than the prothorax, at apex nearly one-half wider than the latter; disk distinctly wider than long, feebly convex; stria one nearly straight, two slightly arcuate, united with one at one-third the length from the apex, three two-thirds and four one-half as long as the elytra respectively, all deeply impressed. Abdomen nearly as wide as and distinctly longer than the elytra. Legs rather short and robust. Length $1.8 \mathrm{~mm}$.

California (Placer Co. 1).

Described from the female. It can very readily be distinguished from all the species previously known by its slender form, short elytra and peculiar disposition of the elytral striæ.

\section{SONOMA Casey.}

S. corticina n. sp. - Linear, depressed, pale testaceous throughout; pubescence fine, rather short, not dense. Head slightly wider than long, a little shorter and narrower than the prothorax; eyes small, at the middle of the sides; genæ long, rounded, longer than the eyes and nearly as prominent; front feebly convex, impunctate, having, at nearly one-third the length from the base, two small nude punctiform fover, mutually slightly less dis. tant than elther from the eye, and, at the vertex, behind the line of the antennæ, a large, deep circular fovea which is completely nude; antennæ onethird longer than the head and prothorax together, slender, feebly clubbed, first joint much longer and slightly more robust than the second, the latter nearly one-half longer than wide, oval, joints three to eight moniliform, gradually shorter, the latter slightly wider than long, joints eight to ten similar in form, gradually slightly larger, eleventh slightly wider than the tenth, a little longer than wide, obtusely acuminate, not as long as the two preceding together; under surface transversely and feebly impressed just behind the mentum, and more deeply so along the basal margin; fourth joint of the maxillary palpi longer than wide, compressed, oval, having a distinct terminal process. Prothorax widest in the middle; sides broadly rounded to the neck, convergent and distinctly sinuate near the base; disk 
slightly wider than long, feebly convex, having a transverse anteriorly arcuate impress.on near the base which terminates laterally in two small punctiform fover and which is more deeply impressed in the middle, also just before the middle two minu te punctiform fovex, separated by one-fifth the entire width, and at each edge at one-fourth the length from the base, a large disconnected deeply impressed fovea, the impression being continued more feebly to the basal angles. Elytra depressed, at the humeri slightly wider than the pronotum; sides nearly parallel, more strongly arcuate behind; together truncate at apex, nearly as loug as the head and prothorax together; sutural strix deeply impressed, begiuning at a slight distance from the base; discal broadly impressed, vanishing near the middle, coarsely foveo-punctate; between this and the sutural a few foveute punctures near the base arranged lougitudinally. Abdomen slightly longer and wider than the elytra; border wide, slightly inclined; first visible dorsal much shorter than the second, having near the apex a transverse interrupted spongiose line. Legs rather short and robust. Lengtb 1.4-1.6 $\mathrm{mm}$.

\section{California (Mendocino Co. 8).}

This species was found rather abundantly under the bark of fallen trees in the Anderson Valley; it differs from parviceps in its larger head, and from isabellce in color and in its less robust form.

S. cavifrons n. sp.--Slender, depressed, pale testaceous throughout; pubescence fine, short, suberect, not dense; integuments polished. Head small, much smaller and narrower han the prothorar, as long as wide; eyes moderate in size, prominent, tinely granulate; genæ convergent, rounded, not at all prominent, as long as the eyes; base feebly sinuate; surface impunctate, having posteriorly two small round feebly impressed foveæ, mutually slightly less distant than either from the eye, and, just behind the strongly elevated transverse frontal ridge, a longitudinally elongated, very deeply excavated fovea which is slightly spongiose and more attenuated posteriorly; antennw slender, slightly longer than the head and prothorax together; first joint longer than wide, robust, oval, second shorter, less robust, oval, one-half longer than wide, third small, narrowest, four to seven subequal, much larger than the third, joints three to seven slightly longer than wide, eight as wide as long, nine and ten slightly larger, very little wider than long, eleventh slightly wider than the tenth. longer than wide, acuminate, shorter than the two preceding together. Prothorax widest at one-third the length from the apex, where it is distinctly wider than long; sides strongly rounded, convergent and sinuate toward base; the latter broadly arcuate, three-fourths as wide as the disk. more than one-third wider than the apex. Elytra at the humeri distinctly wider than the prothordx; sides feebly divergent, more strongly arcuate behind; together slightly longer than wide, as long as the 
head and prothorax together, depressed; sutural series of four impressed foveæ at the base; the sutural stria deeply impressed and continnous only from the fourth fovea; discal impression coarsely foveate, terminating before the middle; between them a basal series of two or three fover. Abdomen as wide as and slightly longer than the elytra; border wide. Legs short and rather slender. Length $1.9 \mathrm{~mm}$.

\section{California (Mendocino Co. 1).}

The pronotal fover and spongiose band of the abdomen are nearly as in corticina. This species is abundantly distinguished from the preceding and from isabellce, Lec. by its smaller head and pale color respectively, and from parviceps Mäkl, which it must more nearly resemble, in its smaller size. The present species was found with the preceding under bark, and, as the Alaskan form inhabits grassy places, the two are probably distinct.

S. isabellce Lec.-Two specimens of this species, collected by Mr. C. Fuchs, at Alameda, differ greatly from those here described in the shorter, more robust antennæ, with more transverse joints, in the intense black color with testaceous elytra, and in the complete absence of the two discal punctures of the pronotum. They were found in decomposing vegetable mould.

\section{EXPLANATION OF THE PLATE.}

The accompanying plate is somewhat experimental, the figures being reproductions by means of photography and gelatine printing, of shaded leadpencil drawings. Should this attempt be deemed successful, the process must assuredly become popular among entomologists, as it is far easier and less trying to the eyesight to make satisfactory drawings in soft pencil than in ink stipple.

Fig. 1-Nisaxis cincinnata Cas.

Fig. 2-Biotus formicarius Cas.

Fig. 3-Eutrichites (Zimmermanni?) Lec.

Fig. 4-Ornpus interruptus Cus.

Fig. 5-Bryaxis texana Cas.
Fig. 6-Tychus sonomice Cas.

Fig. 7-Actium pallidum Cas.

Fig. 8-Rhexidius granulosus Cas. Fig. 9-Thesium laticolle Cas. Fig.10-Sonoma corticina Cas.

Note.-The drawings are taken from typical representitives in all cases excert Eutrichites Lec. and Thesium laticolle Cas., which I have identified from the original descriptions. With reference to the former, it may be stated that the specimen figured agrees very well generically, but not so well specifically, with the description of Le Conte. For example, the apical fovea of the front is stated to be smaller than the occipital in Zimmermanni, whereas in the representative figured it is in the form of a broad, indefinite impression without trace of fovea. The specimens here figured were found at Austin, Texas. 

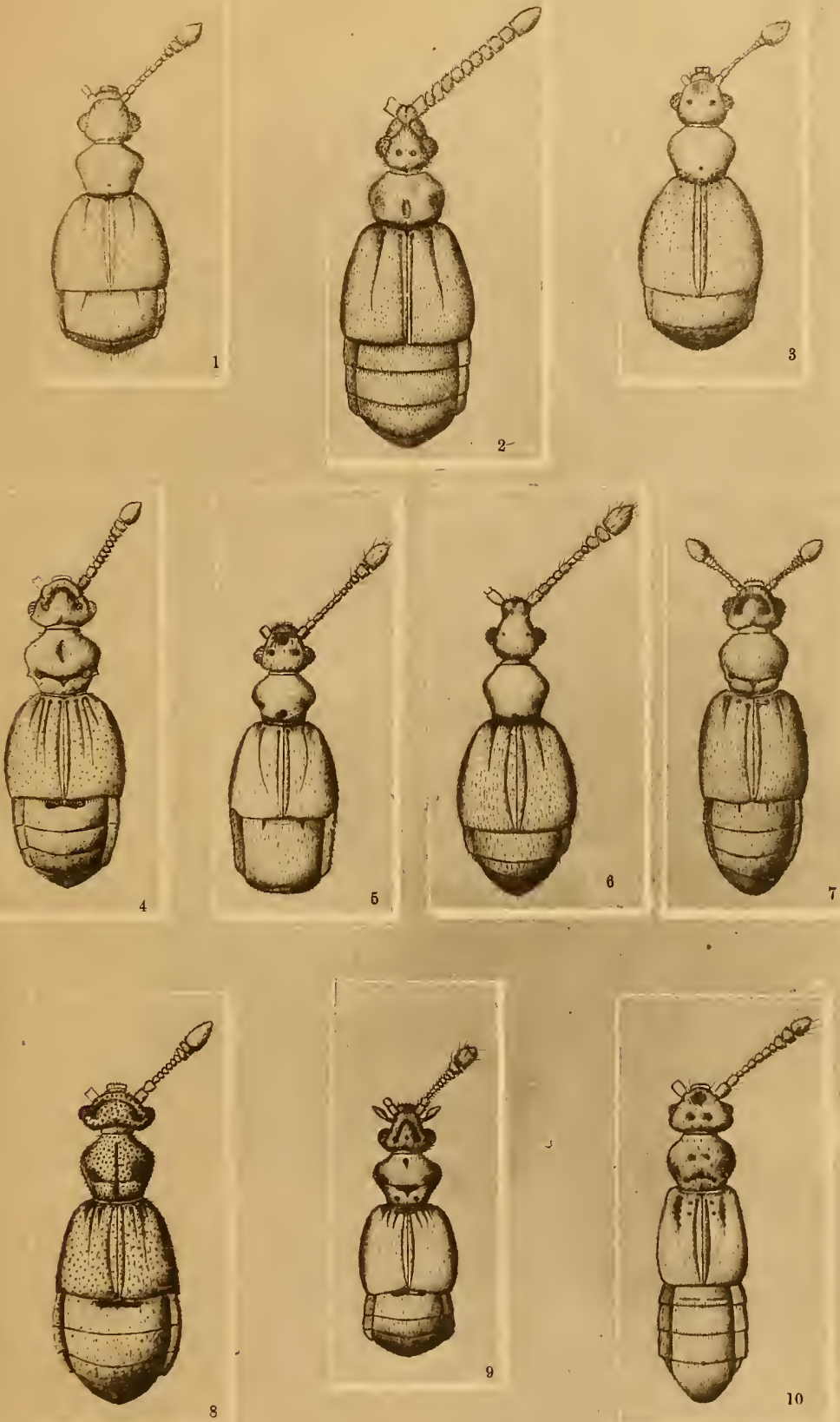

T.L.C. 



\section{$=-$}

\section{-}

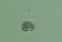

$=$

-.

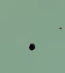

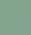




QL Casey, Thomas Lincoln, 1857.

$596-1925$. P8C3 On some new North AmeriEnt. can Pselaphidae. 
